\title{
Az izolált septum pellucidum hiány praenatalis diagnosztikája ultrahang- és mágneses rezonancia képalkotó vizsgálattal
}

\author{
Nemcsik-Bencze Zsófia ${ }^{1}$. Várbíró Szabolcs dr. ${ }^{2}$ \\ Rudas Gábor dr. ${ }^{1}$ - Nemcsik János dr. ${ }^{3,4}$
}

\author{
${ }^{1}$ Semmelweis Egyetem, Általános Orvostudományi Kar, Neuroradiológiai Tanszék, Budapest \\ ${ }^{2}$ Semmelweis Egyetem, Általános Orvostudományi Kar, Szülészeti és Nőgyógyászati Klinika, Budapest \\ ${ }^{3}$ Semmelweis Egyetem, Általános Orvostudományi Kar, Családorvosi Tanszék, Budapest \\ ${ }^{4}$ Zuglói Egészségügyi Szolgálat (ZESZ), Budapest
}

\begin{abstract}
A septoopticus dysplasia, vagy más néven De Morsier-szindróma egy ritka, az agy középvonali képleteit érintő rendellenesség, mely a septum pellucidum hiányával, hypophysis-diszfunkcióval, látóideg-hypoplasiával és mentális visszamaradottsággal jár együtt. A septum pellucidum hiánya önmagában is előfordulhat izolált formában, de ennek septoopticus dysplasiától való praenatalis elkülönítése jelentős diagnosztikai kihívást jelent. Az izolált septum pellucidum hiány a kevés, rendelkezésünkre álló irodalmi adat alapján ártalmatlan anatómiai variáció. Esetbemutatásunkban a magas mágneses térerôvel végzett magzati mágneses rezonancia (MR) képalkotó vizsgálat segítette az izolált septum pellucidum hiány septoopticus dysplasiától való elkülönítését azáltal, hogy lehetővé tette a látóidegek és a chiasma pontosabb megítélését, valamint az esetleges egyéb agyi rendellenességek kizárását. A szülés utáni kétéves követési periódus alatt a gyermek normális szomatomentális fejlődést mutatott mindennemú hormonális és vizuális eltérés nélkül. Esetbemutatásunk megerôsíti, hogy a septum pellucidum izolált hiánya önmagában lehet egy tünetmentes anatómiai variáció, melynek praenatalis diagnosztikai algoritmusában a vizuális traktus és az agyszerkezet pontosabb megítélése kapcsán a magas mágneses térerôvel végzett magzati MR-vizsgálat kulcsfontosságú szerepet játszik, és lehetőséget biztosíthat a septoopticus dysplasia praenatalis kizárására.
\end{abstract}

Orv Hetil. 2020; 161(52): 2195-2200.

Kulcsszavak: izolált septum pellucidum hiány, septoopticus dysplasia, magzati MR, praenatalis diagnózis

\section{Prenatal diagnosis of isolated agenesis of the septum pellucidum with ultrasound and magnetic resonance imaging}

Septo-optic dysplasia is characterized as a midline anomaly with agenesis of the septum pellucidum, optic nerve hypoplasia and pituitary dysfunction. The septal agenesis can occur in isolated form, but its prenatal differentiation from septo-optic dysplasia can be challenging. The isolated agenesis of septum pellucidum is an asymptomatic anatomical variation, based on the few literature data available. We report a case where prenatally performed high magnetic field magnetic resonance imaging helped the differential diagnosis by visualizing and assessing thickness of the optic nerves and chiasma. The development of the infant was followed for 24 months and showed no abnormalities. Our case report confirms that isolated agenesis of the septum pellucidum is probably an asymptomatic variation and the visualization of the optic nerves with high magnetic field fetal MRI could be a crucial point of the differential diagnosis and provide possibility to exclude septo-optic dysplasia in utero.

Keywords: isolated agenesis of the septum pellucidum, septo-optic dysplasia, fetal MRI, prenatal diagnosis

Nemcsik-Bencze Zs, Várbíró Sz, Rudas G, Nemcsik J. [Prenatal diagnosis of isolated agenesis of the septum pellucidum with ultrasound and magnetic resonance imaging]. Orv Hetil. 2020; 161(52): 2195-2200.

(Beérkezett: 2020. május 20.; elfogadva: 2020. június 8.) 


\section{Rövidítések}

ACTH $=$ (adrenocorticotropic hormone) adrenokortikotrop hormon; $\mathrm{GH}=$ (growth hormone) növekedési hormon; $\mathrm{MR}=$ (magnetic resonance) mágneses rezonancia; $\mathrm{SOD}=$ septoopticus dysplasia; $\mathrm{TSH}=$ (thyroid-stimulating hormone) pajzsmirigy-stimuláló hormon

De Morsier 1956-ban írta le elsőként azt a leggyakrabban septoopticus dysplasia (SOD) néven említett, az agy középvonali struktúráit érintő, változatos klinikai tüneteket mutató kórképet, melyre a látóideg és a hypophysis eltérései mellett a septum pellucidum hiánya hívja fel leginkább a figyelmet.

A septum pellucidum az oldalkamrák között elhelyezkedő, szürke- és fehérállományi rostokat tartalmazó, két membrán által létrehozott hártyaszerú képlet. A magzati élet során a két membrán között folyadékkal kitöltött tér helyezkedik el, melyet cavum septi pellucidinek neveznek. A két membrán a születést követően általában záródik, létrehozva a septum pellucidum végleges formáját.

Ez a képlet nemcsak az oldalkamrákat határolja el egymástól, hanem elülső és alsó részével szorosan kapcsolódik a corpus callosumhoz, valamint hátsó és alsó részével a fornix testéhez. Bár a septum pellucidum a limbicus rendszer részét képezi, pontos szerepét idáig nem sikerült meghatározni.

A septum pellucidum részleges vagy teljes hiánya egy ritka, középvonali anomália, mely az átlagpopulációban 100000 emberből átlagosan 2-3 föt érint $[1,2]$. Ez a jelenség ritkán fordul elő izolált formában, általában valamilyen más, a központi idegrendszert érintő kórképhez társul, mint a SOD, a corpus callosum fejlődési rendellenességei, holoprosencephalia, porencephalia, schizencephalia és Chiari II. típusú agyi malformáció, de különböző kéregfejlődési rendellenességek, úgymint polymicrogyria és encephalokele kapcsán is elófordul $[1,3]$.

Másodlagos formában is létrejöhet septum pellucidum hiány, melyet általában a középvonali képleteket érintő, hosszan tartó roncsoló erőhatások hoznak létre. Ilyen például a krónikus progresszív hydrocephalus, a septum pellucidum hártyáit érintő tartós vascularis károsodás, a struktúrát károsító tumoros folyamat vagy sérülés.

A második és a harmadik trimeszterben elvégzett magzati ultrahangvizsgálatok során kiemelkedő fontosságú a cavum septi pellucidi ábrázolása, ugyanis jelentős támpontot nyújt a magzati előagy megfelelő fejlődése szempontjából. Ha a septum pellucidum hiányához más középvonali strukturális eltérések is kapcsolódnak, akkor a leggyakrabban a SOD gyanúja merül fel.

A jelenleg elérhető irodalmakban nem került leírásra egységes differenciáldiagnosztikai protokoll az izolált septum pellucidum hiány és a SOD-hoz kapcsolódó septum pellucidum hiány praenatalis elkülönítésére vonatkozóan $[2,4]$, valamint kevés információ áll rendelkezésünkre az izolált septum pellucidum hiánnyal diagnosztizált gyermekek hosszú távú szomatomentális fejlődésével kapcsolatban.

A biztonságos praenatalis elkülönítés azért lenne hasznos, mert SOD esetén a társuló rendellenességek okán második trimeszterbeli felismerésekor - a heterogén fenotípustól függően - célszerú felajánlani a betegnek a középidős vetélésindukciót, ugyanakkor az izolált septum pellucidum hiány feltehetóen ártalmatlan variáns, melynek követése elegendő.

\section{Esetbemutatás}

2018 februárjában egy 29 éves, egészséges primigravida jelentkezett nőgyógyászánál a 25 . gesztációs héten végzett magzati ultrahangvizsgálatot követően, melynek során a cavum septi pellucidi nem volt azonosítható, így felvetődött a SOD lehetősége.

Anamnéziséből a napi $50 \mathrm{mg}$ propiltiouracillal kezelt Grawes-Basedow-kóron kívül egyéb érdemi megbetegedés, káros szenvedély vagy más gyógyszerfogyasztás nem volt kiemelhető.

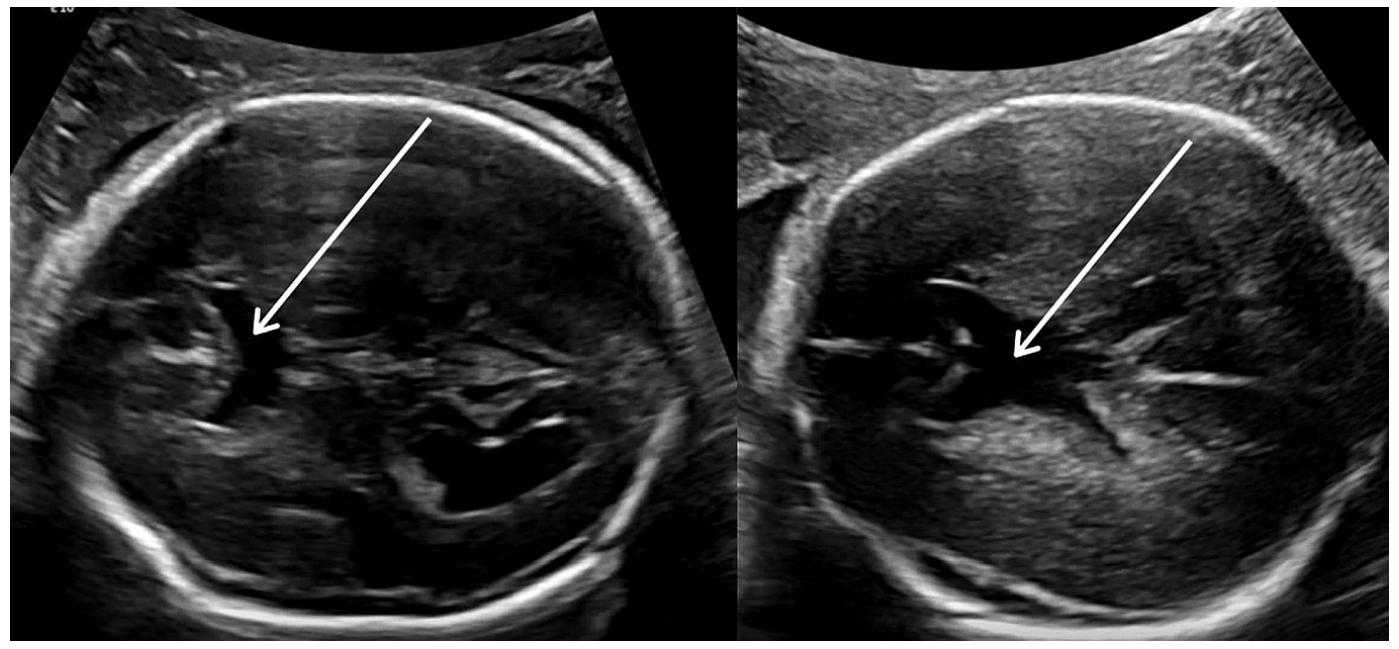

1. ábra

| Az axiális síkú, 2D ultrahangvizsgálaton a frontális kamraszarvak fúziója és a cavum septi pellucidi hiánya látható (fehér nyilak) 


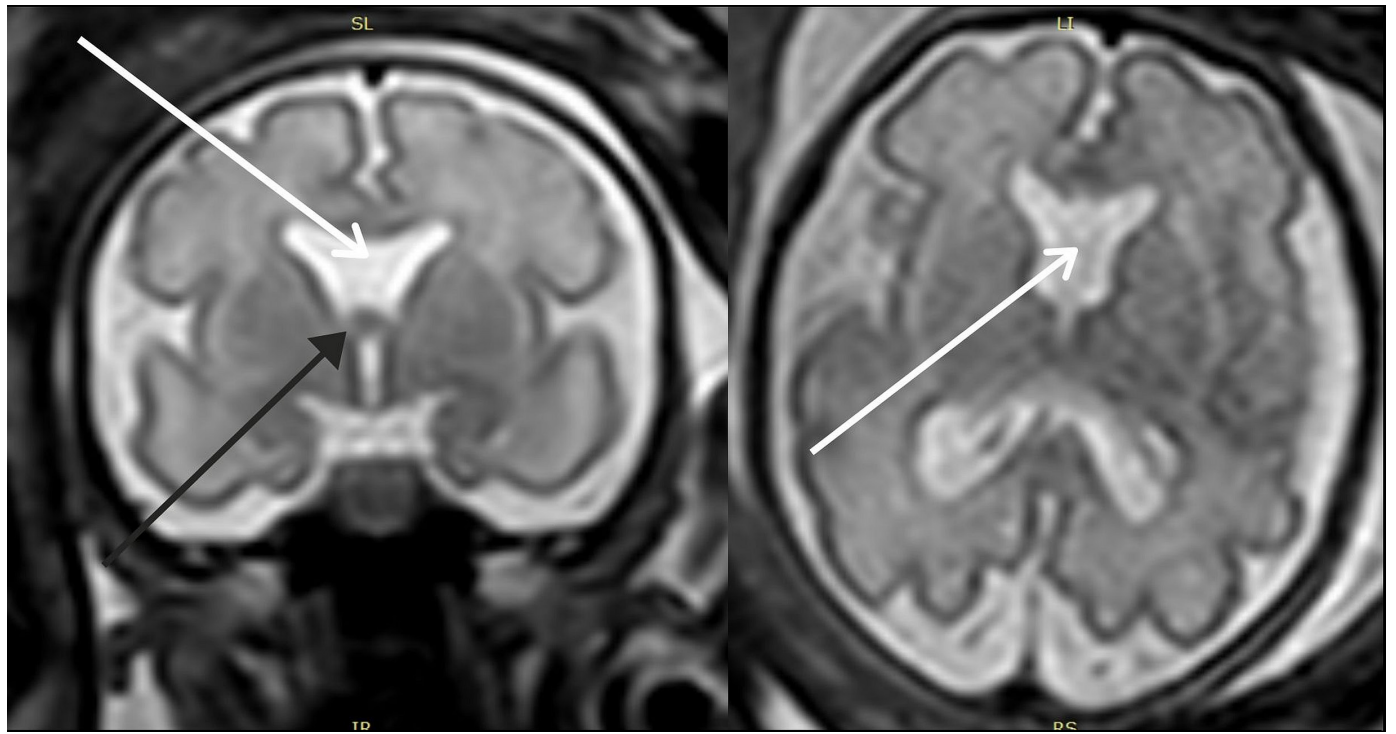

2. ábra

A T2-súlyozott, koronális és axiális síkú MR-felvételek megerősítették a cavum septi pellucidi hiányát (fehér nyilak), valamint a fornix testének alacsonyabb elhelyezkedését mutatták (fekete nyíl)

$\mathrm{MR}$ = mágneses rezonancia

További kontroll 2D és 3D ultrahangvizsgálatok során a frontális kamraszarvak fúziója mutatkozott, valamint a cavum septi pellucidi hiánya került leírásra (1. ábra). A corpus callosum teljes hosszában ábrázolódott, és normális morfológiát mutatott. Egyebekben normális agyszerkezet került leírásra, és más központi idegrendszeri rendellenesség, ventriculomegalia sem volt azonosítható.

A 28. gesztációs héten nagy mágneses térerővel (3 Tesla) rendelkező készülék segítségével mágneses rezonancia (MR) képalkotó vizsgálat készült a magzati vizuális traktus és a hypophysis pontosabb megítélése céljából. A nagy mágneses térerő hatására az eltérő szövetekből nyert magasabb jelintenzitásnak köszönhetően lehetőség nyílik a különböző anatómiai struktúrák pontosabb ábrázolására. Ingenia 3.0T (Philips, Amszterdam, Hollan-

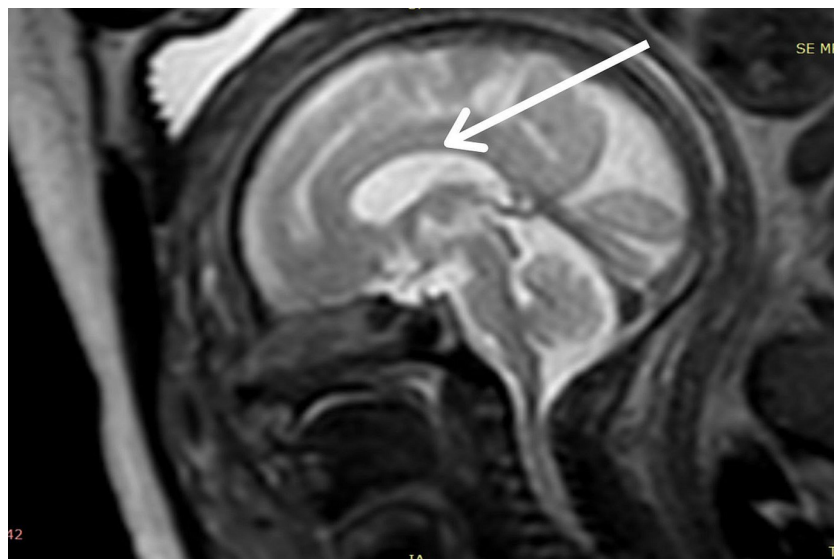

3. ábra

$\begin{aligned} & \text { A sagittalis síkú, T2-súlyozott MR-felvételen a corpus callosum } \\ & \text { teljes hosszában ábrázolódott, és nem mutatott szerkezeti elté- } \\ & \text { rést (fehér nyíl) }\end{aligned}$
MR = mágneses rezonancia

dia) vizsgálóberendezés segítségével 3 mm-es, T2-súlyozott mérések készültek a magzati koponyáról, valamint kiegészítő, 2 mm szeletvastagságú T2-súlyozott mérések a látóidegek síkjára döntve. A vizsgálat során csak a cavum septi pellucidi elülső és hátsó szakaszának részleges maradványai voltak azonosíthatók (2. ábra), egyebekben az agyszerkezet és a gyrificatio a gesztációs életkornak megfelelő volt, és a corpus callosum is eltérés nélkül ábrázolódott (3. ábra). A külső és belső liquorterek szabályosak voltak. Egyéb szerkezeti eltérések, corticalis defektusok nem voltak azonosíthatók. A nagy felbontású vizsgálati technikának köszönhetően a látóidegek és a chiasma megfelelően ábrázolódtak, és a magzati életkornak megfelelő normálszerkezetet mutattak (4. és



4. ábra A koronális síkú, T2-súlyozott MR-felvételen jól kivehető a megfelelő alakú és szerkezetű chiasma (fehér nyíl)

$\mathrm{MR}=$ mágneses rezonancia 


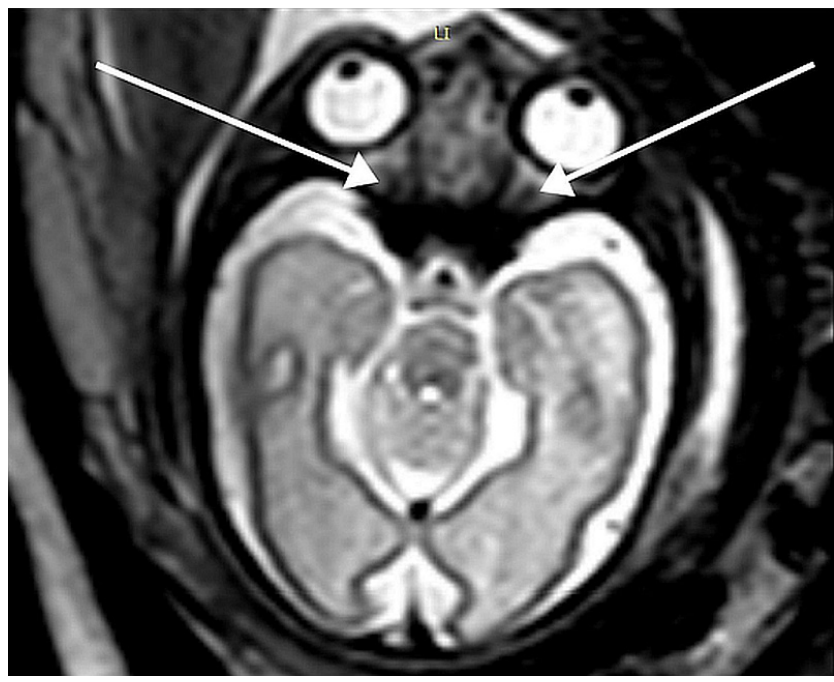

5. ábra

A nervus opticus síkjára döntött axiális síkú, T2-súlyozott MR felvételen jól láthatók a gesztációs életkornak megfelelő vastag ságú látóidegek (fehér nyilak)

$\mathrm{MR}=$ mágneses rezonancia

5. ábra); a nervus opticusok átmérője $3 \mathrm{~mm}$ vastagságú volt, ami szintén a gesztációs életkornak megfelelő [57].

Szülői hozzájárulás hiányában cordocentesist nem végeztünk. A szérumösztriol meghatározása technikai okok miatt meghiúsult, így sem direkt, sem indirekt módon nem sikerült információt nyerni a hypophysis diszfunkciójára utaló magzati hormonértékekról.

Habár a cavum septi pellucidi hiányán kívül sem az ultrahang-, sem az MR-vizsgálat nem mutatott más eltérést, a SOD-ot nem lehetett teljes bizonyossággal kizárni, de a megfelelő vastagságú látóidegek, a normál szerkezetü chiasma és a hypophysis megléte egészséges magzatra utalt.

További problémamentes terhességi szakaszt követően 2018 júniusában, a 38. gesztációs héten az édesanya érett, 3200 grammos fiúgyermeknek adott életet. A korai adaptációs szakasz problémamentesen zajlott. A születést követően elvégzett koponya-ultrahangvizsgálat megerôsítette a septum pellucidum hiányát, de egyebekben más morfológiai eltérést nem talált. A neonatológiai és neurológiai vizsgálatok szintén negatív eredményt mutattak. Az újszülött szérumglükóz- és -TSH-értékei a normáltartományban voltak.

A születést követő kétéves követési periódusban a gyermek a korának megfelelő szomatomentális fejlődést mutatott, mindennemű neurológiai, hormonális és visusbeli eltérés nélkül.

\section{Megbeszélés}

Esetismertetésünk bemutatja, hogy a magas mágneses térerővel végzett MR-vizsgálat segítheti a SOD és az izolált septum pellucidum hiány praenatalis elkülönítését, valamint rávilágít, hogy önmagában az izolált septum pellucidum hiány tünetmentes anatómiai variáció, mely nem jár negatív következményekkel a gyermek szomatomentális fejlődésére. Az izolált septum pellucidum hiány a prevalenciája alapján Magyarországon évente 2-3 terhességet érinthet $[1,3]$.

A SOD változatos klinikai tüneteket mutató kórkép, mely járhat egy- vagy kétoldali látóideg-sorvadás okozta látáskárosodással vagy teljes vaksággal, a hypophysis diszfunkciója kapcsán létrejött hormonális eltérésekkel, valamint az enyhétől a súlyos fokig terjedő mentális retardációval $[8,9]$. A septum pellucidum részleges vagy teljes hiánya előfordulhat önállóan is, egyéb agyszerkezeti eltérés nélkül, de ritkaságának következtében csak kevés irodalom érhető el vele kapcsolatban.

Esetismertetésünkhöz hasonlóan más esettanulmányok is elérhetők a perinatalis időszakból, melyek megerősítik az izolált septum pellucidum hiány benignus voltát $[4,10-12]$. Ezeken túlmenően három olyan, hosszú távú utánkövetéses vizsgálat érhető el, melyekbe több alany is bevonásra került, és célzottan az izolált septum pellucidum hiánnyal foglalkoznak, megpróbálva kizárni a járulékos agyi rendellenességeket és a SOD-ot [13-15]. A 2010-ben Damaj és mtsai által publikált vizsgálatban a születést követően 5 hónapos és 6 éves kor között követték a gyermekeket. A 17 alanyból 14 normális szomatomentális fejlődést mutatott. 3 gyermeknél fejlődésbeli elmaradás mutatkozott, és a további vizsgálatok során SOD igazolódott [13]. A 2018-ban Pilliod és mtsai által közölt tanulmányban 15 gyermeket vizsgáltak, akik közül 11 megfelelő szomatomentális fejlődést mutatott. 2 gyermek az extrém koraszülöttség következtében elhunyt, másik 2 gyermeknél postnatalisan SOD igazolódott [14]. A Vawter-Lee és mtsai által 2018-ban megjelent tanulmányban a vizsgálatba bevont 8 gyermekből 2 gyermek esetében mutatkozott eltérés. Az egyik gyermeknél multifocalis cerebellaris haemorrhagia, a másiknál SOD-nak megfelelő hormonális eltérések mutatkoztak a septum pellucidum hiánya mellett. Az utánkövetést a gyermekek 10 hónapos és 6 éves kora között végezték [15]. Mindhárom tanulmányban a szülést követően a gyermekek hormonális és ophthalmologiai statusa is felmérésre került a SOD kizárására, valamint az esetek többségében postnatalis MR-vizsgálat is készült az izolált septum pellucidum hiány megerősítésére, valamint az esetleges rendellenességek kiszűrésére. Az izolált septum pellucidum hiány felnőttkori előfordulásáról még kevesebb adat áll rendelkezésünkre. Csupán egy, incidentálisan felfedezett septum pellucidum hiány került közlésre Cihangiroglu és mtsai által 2002-ben, egy 19 éves, fejájás miatt vizsgált nőbeteg kapcsán [16]. A fent említett irodalmak és az általunk közölt esetbemutatás is megerósíti ennek a ritka, középvonali anomáliának a kedvező prognózisát, melynek praenatalis elkülönítése az említett irodalmak tükrében még hangsúlyosabbá válik.

Korábbi tanulmányok kimutatták, hogy a radiológiai és a hormonális eltérések szorosan összefüggenek [17- 
19], ezért a magzati hormonszintek meghatározása szintén fontos a differenciáldiagnózis szempontjából. A magzati hormonháztartás zavarát jelezheti a csökkent anyai ösztriolszint. A magzati, mellékvese-eredetű androgén hormonok befolyásolják a placenta által termelt ösztriolmennyiséget, így a terhesség során a csökkent anyai ösztriolérték összefüggésbe hozható a magzati hypophysis múködési zavaraival, valamint a mellékvese által termelt ACTH nem megfelelő szintjével [17]. További magzati hormonszintek - úgymint a TSH, a növekedési hormon $(\mathrm{GH})$ vagy a prolaktin - direkt módon meghatározhatók cordocentesis útján, teljes képet adva a magzati hormonháztartás állapotáról. Sajnos esetünkben technikai okok miatt sem direkt, sem indirekt módon nem került sor a hormonszintek meghatározására.

Habár lehetőség van a magzat látóidegeinek ultrahanggal történő detektálására, ez a képalkotó modalitás az alacsony térbeli felbontás, valamint a magzat esetleges kedvezőtlen fekvése miatt nem mindig teszi lehetővé a vizuális traktus megfelelő megítélését $[14,20]$. A magzati MR-vizsgálat lehetőséget biztosít az anatómiai struktúrák pontosabb ábrázolására, valamint a SODszindrómához társuló esetleges egyéb, agyszerkezeti eltérések kimutatására, mint a hypophysis részleges vagy teljes hiánya, a schizencephalia, a hypoplasticus megjelenésû látóidegek és chiasma vagy a jelen lévő kéregfejlődési rendellenességek.

A látóidegek és a chiasma hypoplasticus megjelenése szinte mindig együtt jár a SOD-szindrómával [19-21], ezért a normálmorfológiát mutató vizuális traktus kedvezőbb prognózist feltételez. Ennek tükrében a látóidegek és a chiasma morfológiai megítélésére nagy hangsúly helyeződik az izolált septum pellucidum hiány differenciáldiagnózisa során.

\section{Következtetés}

Esetbemutatásunk megerősíti a magas mágneses térerővel végzett $M R$-vizsgálatok szerepét az izolált septum pellucidum hiány és az egyéb, a septum pellucidumot érintő eltérések praenatalis differenciáldiagnosztikájában. A látóidegek és a chiasma MR során igazolt normális anatómiája valószínúsíti a kedvező kimenetelt, de a diagnózis megerôsítésére magzati hormonvizsgálatok, illetve az anyai ösztriolszint meghatározása is javasolt. Az izolált septum pellucidum hiány kedvező prognózisa miatt ezeknek a terhességeknek a megtartását javasoljuk, míg második trimeszterbeli felismeréskor SOD esetében szóba jön a középidős vetélésindukció - ezért tartjuk fontosnak a differenciáldiagnosztika ismertetését.

Anyagi támogatás: A közlemény megírása és a kutatómunka anyagi támogatásban nem részesült.

Szerzôi munkamegosztás: N.-B. Zs.: Adatgyüjtés, elemzés, a kézirat végleges megszövegezése. V. Sz.: Kritikai megjegyzések, az eset kezelőorvosi gondozása. R. G.: Kritikai megjegyzések, a beteg neuroradiológiai gondozása. N. J.: témavezető, kritikai megjegyzések, az eset háziorvosi gondozása. A cikk végleges változatát valamennyi szerző elolvasta és jóváhagyta.

Érdekeltségek: A szerzőknek nincsenek érdekeltségeik.

\section{Irodalom}

[1] Barkovich AJ, Norman D. Absence of the septum pellucidum: a useful sign in the diagnosis of congenital brain malformations. Am J Roentgenol. 1989; 152: 353-360.

[2] Malinger G, Lev D, Kidron D, et al. Differential diagnosis in fetuses with absent septum pellucidum. Ultrasound Obstet Gynecol. 2005; 25: 42-49.

[3] Hosseinzadeh K, Luo J, Borhani A, et al. Non-visualisation of cavum septi pellucidi: implication in prenatal diagnosis? Insights Imaging 2013; 4: 357-367.

[4] Lepinard C, Coutant R, Boussion F, et al. Prenatal diagnosis of absence of the septum pellucidum associated with septo-optic dysplasia. Ultrasound Obstet Gynecol. 2005; 25: 73-75.

[5] Haratz K, Viñals F, Lev D, et al. Fetal optic nerve sheath measurement as a non-invasive tool for assessment of increased intracranial pressure. Ultrasound Obstet Gynecol. 2011; 38: 646651.

[6] Al-Haddad CE, Sebaaly MG, Tutunji RN, et al. Optic nerve measurement on MRI in the pediatric population: normative values and correlations. Am J Neuroradiol. 2018; 39: 369-374.

[7] Maresky HS, Ben Ely A, Bartischovsky T, et al. MRI measurements of the normal pediatric optic nerve pathway. J Clin Neurosci. 2018; 48: 209-213.

[8] Miller SP, Shevell MI, Patenaude Y, et al. Septo-optic dysplasia plus: a spectrum of malformations of cortical development. Neurology 2000; 54: 1701-1703.

[9] Benson JC, Nascene D, Truwit C, et al. Septo-optic dysplasia: Assessment of associated findings with special attention to the olfactory sulci and tracts. Clin Neuroradiol. 2019; 29: 505-513.

[10] Schmidt-Riese U, Zieger M. Ultrasound diagnosis of isolated aplasia of the septum pellucidum. [Sonographische Diagnose der isolierten Aplasie des Septum pellucidum.] Ultraschall Med. 1994; 15: 286-292. [German]

[11] Celentano C, Prefumo F, Liberati M, et al. Prenatal diagnosis of septal agenesis with normal pituitary function. Prenat Diagn. 2006; 26: 1075-1077.

[12] García-Arreza A, García-Díaz L, Fajardo M, et al. Isolated absence of septum pellucidum: prenatal diagnosis and outcome. Fetal Diagn Ther. 2013; 33: 130-132.

[13] Damaj L, Bruneau B, Ferry M, et al. Pediatric outcome of chil dren with the prenatal diagnosis of isolated septal agenesis. Prenat Diagn. 2010; 30: 1143-1150.

[14] Pilliod RA, Pettersson DR, Gibson T, et al. Diagnostic accuracy and clinical outcomes associated with prenatal diagnosis of fetal absent cavum septi pellucidi. Prenat Diagn. 2018; 38: 395-401.

[15] Vawter-Lee MM, Wasserman H, Thomas CW, et al. Outcome of isolated absent septum pellucidum diagnosed by fetal magnetic resonance imaging (MRI) scan. J Child Neurol. 2018; 33: 693699.

[16] Cihangiroglu M, Bulut S, Yilmaz S. Isolated septum pellucidum agenesis in an adult. J Neuroimaging 2002; 12: 89-91.

[17] Marshall I, Ugrasbul F, Manginello F, et al. Congenital hypopituitarism as a cause of undetectable estriol levels in the maternal triple-marker screen. J Clin Endocrinol Metab. 2003; 88: 4144-4148.

[18] Koizumi M, Ida S, Shoji Y, et al. Endocrine status of patients with septo-optic dysplasia: fourteen Japanese cases. Clin Pediatr Endocrinol. 2017; 26: 89-98. 
[19] Maduram A, Farid N, Rakow-Penner R, et al. Fetal ultrasound and magnetic resonance imaging findings in suspected septooptic dysplasia: a diagnostic dilemma. J Ultrasound Med. 2020; 39: 1601-1614.

[20] Bault JP, Salomon LJ, Guibaud L, et al. Role of three-dimensional ultrasound measurement of the optic tract in fetuses with agenesis of the septum pellucidum. Ultrasound Obstet Gynecol. 2011 ; 37: 570-575.
[21] Lohmüller R, Gangloff AS, Wenzel F, et al. Optic nerve hypoplasia and septo-optic dysplasia. [Optikushypoplasie und septooptische Dysplasie.] Ophthalmologe 2017; 114: 759-766. [German]

(Várbíró Szabolcs dr., Budapest, Üllői út 78/A, 1082 e-mail: varbiro.szabolcs@med.semmelweis-univ.hu)

L. HORVÁth KaTALIN: „AZ UTOLSÓ MONDATTAL KEZDD!” KULKA FRIGYES egy rendílvüli gyógyító emlékére

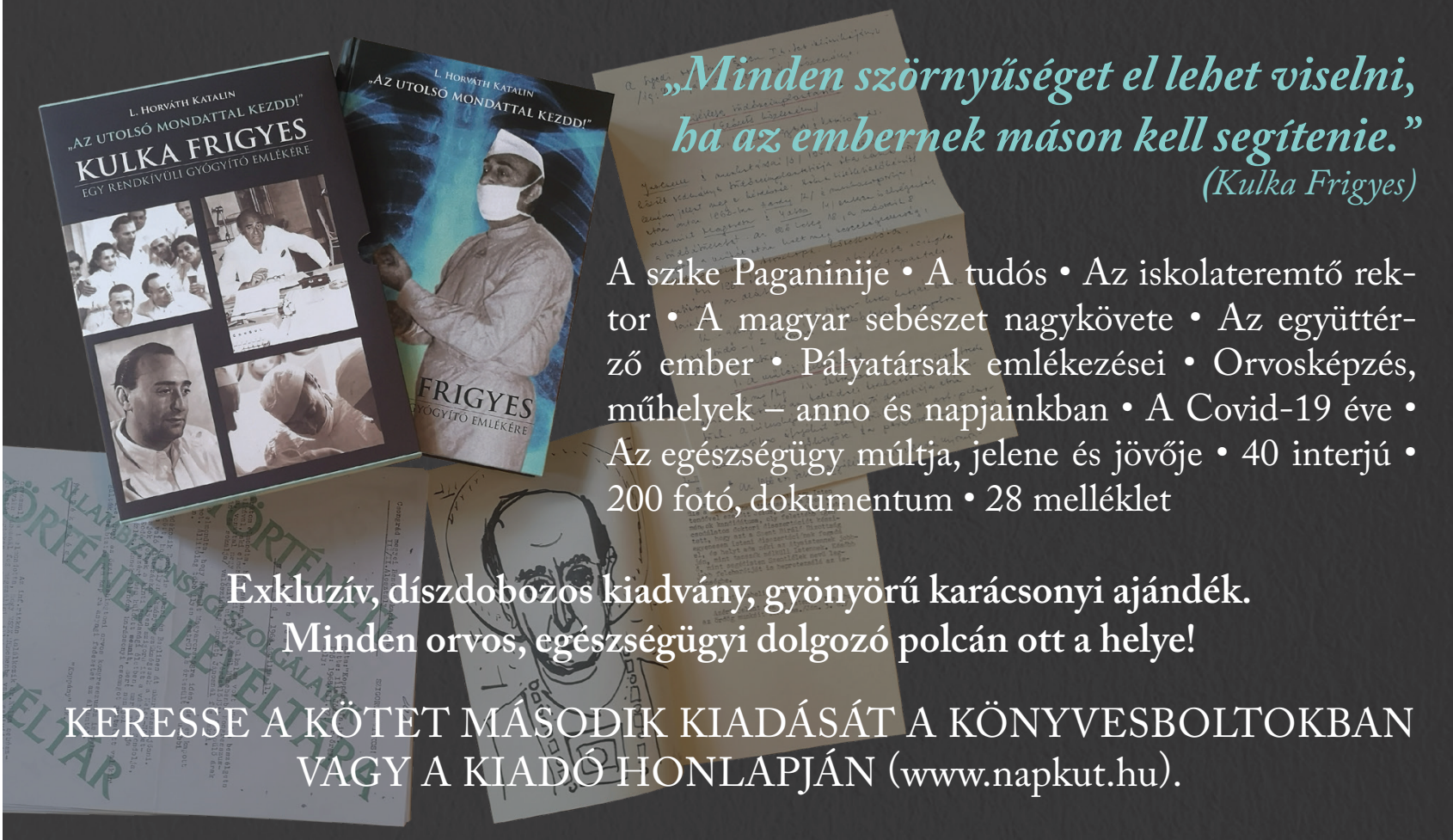

A cikk a Creative Commons Attribution 4.0 International License (https://creativecommons.org/licenses/by/4.0/) feltételei szerint publikált Open Access közlemény, melynek szellemében a cikk bármilyen médiumban szabadon felhasználható, megosztható és újraközölhetö, feltéve, hogy az eredeti szerző és a közlés helye, illetve a CC License linkje és az esetlegesen végrehajtott módositások feltüntetésre kerülnek. (SID_1) 